\title{
Thinking globally and siting locally - renewable energy and biodiversity in a rapidly warming world
}

\author{
Taber D. Allison • Terry L. Root • Peter C. Frumhoff
}

Received: 17 March 2014 / Accepted: 26 March 2014 / Published online: 30 April 2014

(C) The Author(s) 2014. This article is published with open access at Springerlink.com

\begin{abstract}
Increasing greenhouse gas emissions are projected to raise global average surface temperatures by $3^{\circ}-4{ }^{\circ} \mathrm{C}$ within this century, dramatically increasing the extinction risk for terrestrial and freshwater species and severely disrupting ecosystems across the globe. Limiting the magnitude of warming and its devastating impacts on biodiversity will require deep emissions reductions that include the rapid, large-scale deployment of low-carbon renewable energy. Concerns about potential adverse impacts to species and ecosystems from the expansion of renewable energy development will play an important role in determining the pace and scale of emissions reductions and hence, the impact of climate change on global biodiversity. Efforts are underway to reduce uncertainty regarding wildlife impacts from renewable energy development, but such uncertainty cannot be eliminated. We argue the need to accept some and perhaps substantial risk of impacts to wildlife from renewable energy development in order to limit the far greater risks to biodiversity loss owing to climate change. We propose a path forward for better reconciling expedited renewable energy development with wildlife conservation in a warming world.
\end{abstract}

\section{Introduction}

Rapid, large-scale expansion of low- and zero-carbon renewable energy sources is essential for limiting the magnitude of global warming and its impacts on wildlife (Clemmer et al. 2013). Expansion of renewable energy leads to concerns in the conservation community over harm to wildlife populations from injury and death of individual birds and bats or from fragmentation of species' habitat (e.g., Arnett \& Baerwald 2013; Kiesecker et al. 2011).

T. D. Allison $(\square)$

American Wind Wildlife Institute, 1110 Vermont Ave, NW Suite 950, Washington, DC 20005, USA e-mail: tallison@awwi.org

T. L. Root

Stanford University, 473 Via Ortega, Stanford, CA 94305, USA

e-mail: troot@stanford.edu

P. C. Frumhoff

Union of Concerned Scientists, 2 Brattle Square, Cambridge, MA 02138, USA

e-mail: pfrumhoff@uscusa.org 
Threats to wildlife can be reduced by strategic siting and operation, yet the threat of global extinctions rises the longer it takes to reduce carbon emissions (e.g., Warren et al. 2013). Consequently, efforts to expand renewable energy at the needed scale should factor in both (a) the potential for direct harm to species' local populations and (b) the reduction in global biodiversity loss from limiting global warming.

Here we present core issues of this challenge in order to motivate a needed dialogue across conservation and renewable energy communities about determining the acceptable level of uncertainty in the impacts of renewable energy development on wildlife in a world facing high-magnitude warming. We focus on wind energy, but our broader argument applies to other sources of renewable energy. Difficult choices need to be made, and time is of the essence for a dialogue that addresses how to ensure the conservation of wildlife with the need for rapid and deep cuts in greenhouse gas emissions.

\section{Threat of climate change}

Even if we stabilized atmospheric concentrations of heat-trapping gases at today's levels through immediate and deep reductions in emissions, surface temperatures would continue to rise for decades as excess heat now contained in the deep ocean is released to the atmosphere. Adapting to further climate change is unavoidable, but the risks of potentially catastrophic warming can be reduced through deep and sustained cuts in emissions.

The U.S. and other nations agreed to take actions to limit warming below a $2{ }^{\circ} \mathrm{C}$ increase in global average surface temperature above pre-industrial levels (Copenhagen Accord 2009), but actions and pledges by major emitters have fallen far short of what is needed to achieve this goal (World Bank 2012). Future warming most likely will exceed the $2{ }^{\circ} \mathrm{C}$ target (Sanford et al. 2014).

The Intergovernmental Panel on Climate Change (IPCC) reports that a "large fraction" of species around the globe "face increased extinction risk under projected climate change during and beyond the 21 st Century" particularly when the synergistic effects of climate change with other anthropogenic impacts such as habitat loss and fragmentation and invasive species are taken into account. (Scholes et al. 2014). According to the IPCC, the risk of extinction owing to climate change is projected to increase regardless of the scenario used to project future climate change, but the fraction of species at risk will be greater as the magnitude of temperature change increases. For example, most of the world's biodiversity is concentrated in the tropics. Under medium to high magnitude warming, tropical species (characteristically, with quite limited physiological tolerance to changes in climate) will experience monthly average temperatures that exceed historic bounds before 2100 (Mora et al. 2013).

\section{Need for significant renewable energy expansion}

Limiting the magnitude of warming to $\sim 2{ }^{\circ} \mathrm{C}$ will require swift and deep reductions in heattrapping emissions. Assuming comparable actions by other nations, the U.S. would have a carbon budget equivalent to emitting no more than $\sim 170-200$ Gigatons of carbon dioxide between 2012 and 2050, a level consistent with the goal of reducing U. S. emissions by $83 \%$ below 2005 levels by mid-century (NRC, 2010). A large proportion of these reductions will come from the power sector, and meeting this emissions goal will require extensive expansion of renewable energy (Fawcett et al. 2009; Clemmer et al. 2013). Staying within the U.S. carbon budget, for example, will require expansion of land-based wind energy from $60 \mathrm{GW}$ in 
2012 to $330-440 \mathrm{GW}$ in 2050 , and offshore wind expansion from zero currently to $25-100$ GW; estimates for solar energy in 2050 range from 160-260 GW for photovoltaic and 20-80 GW for concentrated solar (Clemmer et al. 2013).

\section{Potential wildlife impacts of renewable energy expansion}

All forms of low-carbon electricity production have environmental impacts, and the potential impacts of wind energy and solar energy development on wildlife have been the subject of multiple reviews (e.g., NRC, 2007; Arnett et al. 2008; Strickland et al. 2011; Lovich \& Ennen 2013). Collision fatalities of birds and bats have been reported at all wind energy facilities where data are publicly available (Strickland et al. 2011); raptors and bats appear to be relatively more vulnerable to collision. Projections of fatality levels under aggressive buildout scenarios raise the concern that reported fatality levels are not sustainable for some of these species (e.g., Johnson \& Erickson 2011; Arnett \& Baerwald 2013). Concern has been expressed about the large land area needed to achieve emissions reduction targets described above (McDonald et al. 2009). Disturbances associated with renewable energy development may cause displacement of sensitive species from otherwise suitable habitat or lead to demographic decline due to effects on breeding success or survival, but the few studies evaluating these effects have not produced definitive or consistent results either within or among species (e.g., Pearce-Higgins et al. 2012; Lovich \& Ennen 2013; Sandercock et al. 2013).

Uncertainty regarding the magnitude of impacts to wildlife from renewable energy development have been influential in siting decisions to date (e.g. BLM 2013) and growing concerns about this potential but unknown risk threaten to undermine the pace and scale of renewable energy development needed to achieve emissions reduction targets.

\section{Proposed framework}

We opened this paper with a simple proposition: efforts to expedite renewable energy expansion while protecting biodiversity need to factor in both (a) the potential adverse impacts of renewable energy siting and operation and related transmission on wildlife and (b) the reduction in extinction risk from avoided emissions and high-magnitude warming. A framework to achieve these objectives includes

1. Continuing efforts to strategically locate and operate renewable energy projects to minimize impacts to wildlife from such development

2. Understanding the potentially far greater risks to global biodiversity from increased extinction owing to unlimited climate change, and

3. Acknowledging that research will not eliminate uncertainty regarding wildlife impacts in advance of the scale of development needed to limit global warming.

Several initiatives are underway to avoid and minimize wildlife impacts of wind energy development, which may constitute up to $50 \%$ of the total renewable energy development by 2050 (e.g., Mai et al. 2012). The U. S. Fish and Wildlife Service released voluntary guidelines for siting land-based wind energy and for developing eagle conservation plans, thus, providing a legal framework for companies to avoid and minimize impacts to species vulnerable to wind energy development (USFWS 2012; USFWS 2013b). 
In 2008 the American Wind Wildlife Institute (www.awwi.org), a partnership among the wind industry, scientific community, and conservation organizations, was formed to foster research and develop tools to promote timely and responsible wind energy development that minimizes impacts to wildlife and wildlife habitat. To address specific concerns about bats, the Bat Wind Energy Cooperative (http://www.batsandwind.org/), a collaboration of the wind industry, Bat Conservation International, and the Department of Energy, was formed in 2003 and has tested mitigation strategies that may reduce bat fatalities by $50 \%$ or more (e.g., Arnett et al. 2013). The multi-partner Sage Grouse Collaborative was established in 2010 and implemented a research framework to determine the impact of wind energy development on this species at multiple sites (National Wind Coordinating Collaborative NWCC 2010).

Incorporating the risks of climate change into siting decisions could lead to decisions that do not appear to be precautionary with respect to biodiversity impacts when only the first of our propositions, avoidance and minimization of local impacts, is considered. For example, in December 2013 the Service finalized an amendment to the 2009 Eagle Rule that extended the duration of programmatic take permits up to 30 years (USFWS 2013a). By allowing a 30-year permit length under certain conditions, the Service made the Eagle Rule more compatible with the long-term assurances requested by the wind industry because of the need to secure funding and lease agreements for developing projects. This revision has been opposed by some in the conservation community because of concerns that longer permit lengths are not compatible with our level of knowledge about eagles or the threat of wind energy development to eagle populations (e.g. American Bird Conservancy 2013).

The predicted and devastating impacts of climate change on biodiversity need to be incorporated into the risk calculus of renewable energy development in ways that they are not today. Even as the conservation community partners with the wind industry to minimize impacts of siting renewable energy, it will be necessary to accept some, and perhaps substantial uncertainty about the risk to wildlife populations if we are to limit the greater risks of global extinctions from unlimited climate change.

Aggressive renewable energy development is essential to both limiting climate change and protecting wildlife. Achieving the needed expansion of renewable energy in the face of concerns about wildlife risks will require (1) a shared understanding among key stakeholders of the scale and pace of renewable energy siting needed to help limit the wildlife impacts of climate change, (2) application of the best available science to renewable energy siting - science that informs an understanding of both the local near-term wildlife risks of siting and the longerterm, global extinction risks of climate change, and (3) a policy framework and timely process for siting decisions that supports renewable energy expansion while taking the full suite of risks and uncertainties into account. We intend this paper to catalyze a series of structured dialogues among industry, wildlife conservation advocates and policymakers in support of this goal.

Open Access This article is distributed under the terms of the Creative Commons Attribution License which permits any use, distribution, and reproduction in any medium, provided the original author(s) and the source are credited.

\section{References}

American Bird Conservancy (2013) Eagle rule weakens current protections and sanctions eagle deaths. ABC News Release. http://www.abcbirds.org/newsandreports/releases/131206.html. Accessed 28 February 2014 Arnett EB, Baerwald EF (2013) Impacts of wind energy development on bats: implications for conservation. In: Adams RA, Pederson SC (eds) Bat evolution, ecology, and conservation. Springer Science + Business Media, New York, pp 435-456 
Arnett EB, Brown WK, Erickson WP, Fiedler JK, Hamilton BL, Henry TH, Jain A, Johnson GD, Kerns J, Koford RR, Nicholson CP, O’Connell TJ, Piorkowski MD, Tankersley RD Jr (2008) Patterns of bat fatalities at wind energy facilities in North America. J Wildl Manag 72:61-78

Arnett EB, Johnson GD, Erickson WP, Hein CD (2013) A synthesis of operational mitigation studies to reduce bat fatalities at wind energy facilities in North America. A report submitted to the National Renewable Energy Laboratory. Bat Conservation International, Austin

Clemmer S, Rogers J, Sattler S, Macknick J, Mai T (2013) Modeling low-carbon US electricity futures to explore impacts on national and regional water use. Environ Res Lett 8:015004

Fawcett AA, Katherine VC, de la Chesnaye FC, Reilly JM, Weyant JP (2009) Overview of EMF 22 U.S. transition scenarios. Energy Econ 31:S198-S211

Johnson GD, Erickson WP (2011) Avian, bat and habitat cumulative impacts associated with wind energy development in the Columbia Plateau Ecoregion of eastern Washington and Oregon. West Inc. Report prepared for Klickitat County Planning Department, Cheyenne

Kiesecker JM, Evans JS, Fargione J, Doherty K, Foresman KR, Kunz TH, Naugle D, Nibbelink NP, Neimuth ND (2011) Win-win for wind and wildlife: a vision to facilitate sustainable development. PLoS ONE 6(4): e17566. doi:10.1371/journal.pone.0017566

Lovich JE, Ennen JR (2013) Assessing the state of knowledge of utility-scale wind energy development and operation on non-volant terrestrial and marine wildlife. Appl Energy 103:52-60

Mai T, Wiser R, Sandor D, Brinkman G, Heath G, Denholm P, Hostick DJ, Darghouth N, Schlosser A, Strzepek K (2012) Exploration of High-Penetration Renewable Electricity Futures. Vol. 1 of Renewable Electricity Futures Study. National Renewable Energy Laboratory, Golden, CO, Tech. Rep. NREL/TP-6A20-52409-1.

McDonald RI, Fargione J, Kiesecker J, Miller WM, Powell J (2009) Energy sprawl or energy efficiency: climate policy impacts on natural habitat for the United States of America. PLoS One 4(8):e6802

Mora C, Frazier AG, Longman RJ, Dacks RS, Walton MM, Tong EJ, Sanchez JJ, Kaiser LR, Stender YO, Anderson JM, Ambrosino CM, Fernandez-Silva I, Giuseffi LM, Giambelluca TW (2013) The projected timing of climate departure from recent variability. Nature 502:v183-196

National Research Council (NRC) (2007) Environmental impacts of wind-energy projects. The National Academies Press, Washington, DC

National Research Council (NRC) (2010) Limiting the magnitude of future climate change. The National Academies Press, Washington, DC

National Wind Coordinating Collaborative (NWCC) (2010) Sage grouse research collaborative. http:// nationalwind.org/research/collaboratives/sage-grouse/. Accessed 21 April 2014

Pearce-Higgins JW, Stephen L, Douse A, Langston RH (2012) Greater impacts of wind farms on bird populations during construction than subsequent operation: results of a multi-site and multi-species analysis. J Appl Ecol 49(2):386-394

Sandercock BK, Wisely SM, McNew LB, Gregory AJ, Winder VL, Hunt LM (2013) Environmental impacts of wind power development on the population biology of Greater Prairie-Chickens. Final Project Report for Award DOE/EE0000526. US Department of Energy, Washington, DC

Sanford T, Frumhoff PC, Luers A, Gulledge J (2014) The climate policy narrative for a dangerously warming world. Nat Clim Chang 4:164-166

Scholes R, Settele J, Betts R, Bunn S, Leadley P, Nepstad D, Overpeck J, Taboada MA, Climate Change (2014) Terrestrial and InlandWater Systems. In: Barros V, Field C (eds) Final Draft Report: Impacts, Adaptation and Vulnerability. Contribution of Working Group II to the Fifth Assessment Report of the Intergovernmental Panel on Climate Change. Cambridge University Press, Cambridge, p 153

Strickland MD, Arnett EB, Erickson WP, Johnson DH, Johnson GD, Morrison ML, Shaffer JA, Warren-Hicks W (2011) Comprehensive guide to studying wind energy/wildlife interactions. National Wind Coordinating Collaborative, Washington, DC

The Copenhagen Accord (2009) The United Nationals Framework Convention on Climate Change, Denmark

The World Bank (2012) Turn Down the Heat: Why a $4^{\circ} \mathrm{C}$ Warmer World Must Be Avoided. Washington, DC

US Bureau of Land Management (BLM) (2013) BLM defers final decision on China Mountain Wind project. US Department of Interior, Bureau of Land Management News Release http://www.blm. gov/id/st/en/media_center/newsroom/2012/March-2012_News/idaho_blm_defers_final.html. Accessed 28 February 2014te

US Fish and Wildlife Service (USFWS) (2012) Final Land-Based Wind Energy Guidelines. Fisheries and Habitat Conservation and Migratory Birds Programs, US Department of Interior, Federal Register 77, 26 March 2012:17496-17498 
US Fish and Wildlife Service (USFWS) (2013a) Eagle Permits; Changes in the Regulations Governing Eagle Permitting. US Department of Interior, Federal Register 78, 9 December 2013:73704-73725

US Fish and Wildlife Service (USFWS) (2013b) Eagle Conservation Plan Guidance. Module 1 - Land-based Wind Energy. Version 2. Division of Migratory Bird Management, US Department of Interior, April 2013

Warren R, VanDerWall J, Price J, Welbergen JA, Atkinson I, Ramirez-Villegas J, Osborn TJ, Jarvis A, Shoo LP, Williams SE, Lowe J (2013) Quantifying the benefit of early climate change mitigation in avoiding biodiversity loss. Nat Clim Chang 3:678-682 